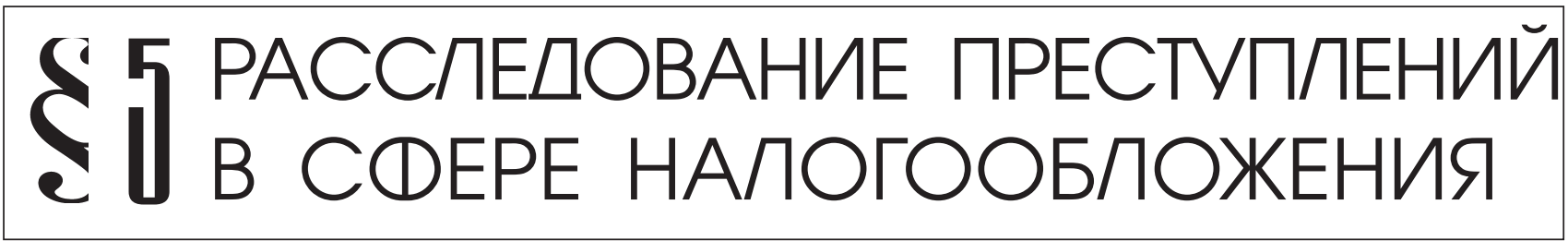

М.О. Акопджанова

\title{
ДИСПОЗИЦИЯ СТАТЬИ 198 УГОЛОВНОГО КОДЕКСА РОССИИ ОБ ОТВЕТСТВЕННОСТИ ЗА УКЛОНЕНИЕ ОТ УПЛАТЫ НАЛОГОВ И СБОРОВ С ФИЗИЧЕСКОГО ЛИЦА
}

Аннотация: Статья посвящена исследованию вопросов «бланкетности» диспозиции нормы российского уголовного законодательства об ответственности за налоговые преступления, рассмотрению основных характеристик, особенностей выявления признаков данного деяния. Анализируются условия возникновения и особенности исполнения налоговой обязанности. $B$ результате исследования действующего уголовного и налогового законодательства, правоприменительной практики обосновывается вывод о необходимости совершенствования ряда норм, регламентирующим процесс перечисления налогов.

В заключение обосновывается вывод о том, что противодействие рассматриваемому налоговому преступлению может быть достигнуто вследствие повышения контроля и взаимодействия правоохранительных и налоговых органов, обеспечивающего выявление и устранение криминогенных факторов. В силу «бланкетности» нормы уголовного закона, содержсачейся в cm. 198 УК РФ, первая может быть применена и совершенствована при неизбежном учёте норм действующего налогового законодательства России, а также правоприменительной практики в соответствующей сфере, позволяющей детализировать признаки состава данного налогового преступления.

Ключевые слова: Юриспруденция, налоги, сборь, законодательство, диспозиция, состав, признаки, преступление, суд, ответственность

татья 198 Уголовного кодекса Российской Федерации (далее - УК РФ) предусматривает уголовную ответственность за «уклонение от уплаты налогов и (или) сборов с физического лица путем непредставления налоговой декларации или иных документов, представление которых в соответствии с законодательством Российской Федерации о налогах и сборах является обязательным, либо путем включения в налоговую декларацию или такие документы заведомо ложных сведений, совершенное в крупном (особо крупном) размере.
Объектом данного преступления являются общественные отношения, обеспечивающие установленный порядок уплаты налогов и сборов и регламентируемые Налоговым кодексом Российской Федерации. Предметом преступления являются налоги и сборы.

В современной юридической литературе имеются различные позиции по вопросу «территориальной определённости» налогов и сборов, уклонение от уплаты которых считается уголовно наказуемым. В частности, в уголовно-правовой литературе было предложено рассматривать в качестве предмета налоговых 
преступлений исключительно федеральные налоги, поскольку, как отмечают авторы, в противном случае бы нарушался принцип равенства граждан России в отношении оснований и пределов уголовной ответственности в зависимости от региона пребывания и деятельности налогоплательщика'. Думается, подобная позиция не вполне соответствует положениям Конституции РФ, в соответствии с которыми «каждый обязан платить законно установленные налоги и сборы», и п.1 ст.3 НК РФ, согласно которому «законодательство о налогах и сборах основывается на признании всеобщности и равенства налогообложения». Указанная в законе «всеобщность обязанности» и «всеобщность налогообложения» предполагает распространение действия законодательства РФ о налогах и сборах как на регулирование федеральных налогов и сборов, так и на регламентацию региональных и местных налогов и сборов. А в связи с тем, что диспозициям «налоговых» статей Уголовного кодекса РФ присущ бланкетный характер функционирования, действие первых также распространяется на уклонение от уплаты как федеральных, так и региональных и местных налогов и сборов ${ }^{2}$.

Подобная позиция нашла отражение и в судебной практике. В частности, в п. 1 Постановления Пленума Верховного Суда РФ от 28 декабря 2006 г. № 64 «О практике применения судами уголовного законодательства об

\footnotetext{
${ }^{1}$ См.: Волженкин Б.В. Преступления в сфере экономической деятельности по уголовному праву - C.666; Егоров B.A. Налоговые преступления и их предупреждение: Автореф. дис. ... канд. юрид. наук. - Самара, 1999. - С.7; Кашубин Д.Ю. Налоговые преступления в уголовном праве России: Автореф. дис. ... канд. юрид. наук. - М., 2002. - С.19 и др.

2 Таким образом, уголовно наказуемым признаётся причинение крупного или особо крупного ущерба как федеральному бюджету, так и региональным и местным бюджетам, что является важной гарантией обеспечения и защиты российского федерализма.
}

ответственности за налоговые преступления»³ указано, что уголовная ответственность по ст. 198 УК РФ наступает в случае уклонения как федеральных налогов и сборов, так и налогов субъектов РФ и местных налогов.

К числу налогов (сборов), плательщиками которых могут являться исключительно физические лица, относятся налог на доходы физических лиц и налог на имущество физических лиц.

Ряд налогов могут уплачиваться как физическими лицами, так и организациями (налог на добавленную стоимость, акцизы, налог на добычу полезных ископаемых, водный налог, сборы за пользование объектами животного мира и за пользование объектами водных биологических ресурсов, государственная пошлина, налог на игорный бизнес, транспортный налог, земельный налог).

Объективная сторона данных преступлений характеризуется действиями (бездействием) в форме уклонения от уплаты налогов и (или) сборов; последствиям в виде причинённого ущерба в крупном размере, а также причинно-следственной связью между указанными действиями (бездействием) и наступившими уголовно наказуемыми последствиями. Важнейшим признаком объективной стороны является способ уклонения - непредставление налоговой декларации или иных документов, представление которых в соответствии с законодательством Российской Федерации о налогах и сборах является обязательным, либо включение в налоговую декларацию или такие документы заведомо ложных сведений.

Термин «уклонение» означает существительное, производное от глагола «уклониться», которое толкуется как «избегая чего-нибудь, устраниться, отказаться от чего-нибудь» ${ }^{4}$ В случае совершения преступления, предус-

\footnotetext{
${ }^{3}$ См.: Бюллетень Верховного Суда РФ. - 2007. - №3.

${ }^{4}$ См.: Ожегов С.И. Словарь русского языка / С.И. Оже2ов. - M., 1994. - C.918.
} 


\section{Налоги и налогообложение - №1(103) • 2013}

мотренного ст.198 УК РФ, налогоплательщик отказывается от выполнения конституционной обязанности платить законно установленные налоги и сборы (ст.57 Конституции РФ).

Исходя из смысла закона, термин «уклонение» определяется как совершение лицом действий (бездействия) по непредставлению налоговой декларации или иных документов, представление которых в соответствии с законодательством Российской Федерации о налогах и сборах является обязательным, либо включению в налоговую декларацию или такие документы заведомо ложных сведений.

В то же время Верховный Суд более широко трактует данное понятие. Так, Пленум Верховного Суда РФ определяет уклонение как «умышленные деяния, направленные на неуплату налогов и сборов в крупном или особо крупном размере и повлекшие полное или частичное непоступление соответствующих налогов и сборов в бюджетную систему РФ» ${ }^{5}$. Таким образом, Верховным Судом РФ к «уклонению» отнесены любые действия (бездействие), совершённые с целью неуплаты налогов (сборов) в крупном (особо крупном) размере и повлекшие наступление указанных последствий.

Думается, определение, приведённое в названном Постановлении Пленума Верховного Суда РФ, основано на обобщении обширной практики применения «налоговых» статей УК РФ и учёте основных теоретических достижений в данной области.

В частности, в уголовно-правовой литературе приведено множество примеров способа уклонения, выявленного в ходе расследования различных уголовных дел о налоговых преступлениях. Так, И.Н. Соловьёв выделяет следующие способы подобного уклонения:

\footnotetext{
${ }^{5}$ П.3 Постановления Пленума Верховного Суда РФ от 28 декабря 2006 г.№64 «О практике применения судами уголовного законодательства об ответственности за налоговые преступления» // СПС «КонсультантПлюс».
}

1) уклонение от регистрации в налоговых органах в качестве налогоплательщика, соответственно, с сокрытием всех объектов налогообложения; 2) сокрытие с использованием различных приемов дохода (прибыли) и иных объектов налогообложения; 3) занижение полученных доходов и завышение произведенных расходов; 4) переложение налоговых обязательств на несуществующие или подложные юридические лица; 5) неотражение оборота товарно-материальных ценностей и денежных средств; 6) отсутствие учета объектов налогообложения при условии их сокрытия; 7) незаконное использование налоговых льгот. При этом автор делает оговорку, что данный перечень является далеко не исчерпывающим ${ }^{6}$.

Д. Г. Макаров к числу подобных способов относит: 1) полное сокрытие всех объектов налогообложения; 2) занижение выручки от реализации товаров (работ, услуг); 3) сокрытие средств от уплаты налогов при наличии недоимки по налогам или с целью ее создания; 4) неправомерное использование льгот. Применительно к отдельным видам налогов указанные способы конкретизируются?

И.И. Кучеров в качестве способов уклонения называет: 1) открытое игнорирование налоговых обязанностей (непредставление бухгалтерской отчетности (декларации) в налоговые органы); 2) выведение субъекта налогообложения из-под налогового контроля (непостановка на налоговый учет; фиктивная реорганизация (ликвидация) организации); 3) неотражение результатов финансово-хозяйственной деятельности в документах бухгалтерского (налогового) учета (осуществление сделок без документального оформления; неотражение

\footnotetext{
${ }^{6}$ См.: Соловьев И. Н. Уголовная ответственность за уклонение от уплаты налогов и сборов / И.Н. Соловьёв. - M., 2000. - C. 91-95.

${ }^{7}$ См.: Макаров Д. Г. Теневая экономика и уголовный закон / Д.Г. Макаров. М., 2003. - С. 27-36.
} 
результатов хозяйственных операций в документах бухгалтерской отчетности; неоприходование товарно-материальных ценностей и денежной выручки); 4) маскировка объекта налогообложения (фиктивный бартер, ложно-экспорт; фиктивная сдача в аренду основных средств; подмена объекта налогообложения; создание искусственной дебиторской задолженности; отражение результатов финансово-хозяйственной деятельности в ненадлежащих счетах бухгалтерского учета); 5) искажение объекта налогообложения (занижение дохода (прибыли); занижение объема (стоимости) реализованной продукции (работ, услуг); занижение стоимости налогооблагаемой недвижимости, автотранспорта, другого имущества); 6) искажение экономических показателей, позволяющее уменьшить размер налогооблагаемой базы; 7) использование необоснованных изъятий и скидок ${ }^{8}$.

В литературе также называются и иные способы совершения уклонения от уплаты налогов (сборов) 9 .

Законодателем в ст.198 УК РФ в качестве способов совершения данных налоговых преступлений называются: непредставление налоговой декларации или иных документов, представление которых в соответствии с законодательством Российской Федерации о налогах и сборах является обязательным; включение в налоговую декларацию или указанные документы заведомо ложных сведений.

\footnotetext{
${ }^{8}$ См.: Кучеров И. Налоги и криминал: Историко-правовой анализ / И.И. Кучеров. - М., 2000. - С. 215-216; Кyчеров И.И., Соловьев И. Н. Уголовная ответственность за налоговые преступления / И.И. Кучеров, И.Н. Соловьёв. - М., 2004. - C. 38-40.

${ }^{9}$ См. например: Александров И.В.: 1) Налоговые преступления: криминалистические проблемы расследования / И.В. Александров. - СПб., 2002. С. 92-118; 2) Основы налоговых расследований/ И.В. Александров. - СПб., 2003. - С. 118-151 и др.
}

Непредставление налоговой декларации или иных документов, представление которых в соответствии с законодательством Российской Федерации о налогах и сборах является обязательным, представляет собой бездействие в форме подобного непредставления документов в срок, установленный налоговым законодательством РФ.

Сроки представления декларации устанавливаются законодательством о налогах и сборах применительно к каждому из существующих видов налогов. Например, по налогу на добавленную стоимость налогоплательщики обязаны представить в налоговые органы по месту своего учета налоговую декларацию в срок не позднее 20 числа месяца, следующего за истекшим налоговым периодом, каковым по общему правилу для уплаты НДС является один календарный месяц (для налогоплательщиков с ежемесячными в течение квартала суммами выручки от товара (работ, услуг), не превышающими 1 млн. рублей, - квартал) - ст. 163, п. 5 ст. 174 НК РФ. Налогоплательщики акцизов обязаны представлять в налоговые органы по месту своего нахождения, а также по месту нахождения каждого своего обособленного подразделения налоговую декларацию за налоговый период (календарный месяц) в срок не позднее 25 числа месяца, следующего за истекшим налоговым периодом. Налогоплательщики, осуществляющие деятельность по реализации алкогольной продукции с акцизных складов розничной торговли, - не позднее 15 числа месяца, следующего за истекшим налоговым периодом; налогоплательщики, имеющие только свидетельство на оптовую реализацию, - не позднее 25 числа второго месяца, а налогоплательщики, имеющие свидетельство на розничную реализацию, - не позднее 10 числа месяца, следующего за истекшим налоговым периодом (п. 1 ст. 229 НК РФ).

Включение в налоговую декларацию или указанные документы заведомо ложных сведе- 


\section{Налоги и налогообложение - №1(103) • 2013}

ний представляет собой включение в первые сведений, не соответствующих действительности, а также документам бухгалтерского учёта и отчётности (в частности, ложных сведений об объекте налогообложения, заниженных показателей прибыли, завышенных показателей расходов, направленное на необоснованную минимизацию налогооблагаемой базы и т.д.).

Осуществлению уголовно наказуемого уклонения от уплаты налогов (сборов) указанными в законе способами могут предшествовать следующие действия (бездействие) недобросовестного налогоплательщика:

1) полное или частичное неотражение результатов финансово-хозяйственной деятельности предприятия в документах бухгалтерского учета: осуществление сделок без документального оформления; неоприходование товарно-материальных ценностей; неоприходование денежной выручки в кассу. Широкое распространение получила практика использования операций с рублевой и валютной наличностью, не фиксируемой в бухгалтерском учете и отчетности («черный нал»);

2) нарушение порядка учета экономических показателей: отражение цифровых результатов финансово-хозяйственной деятельности в ненадлежащих счетах бухгалтерского учета; нарушение правил ведения кассовых операций; нарушение правил списания товарно-материальных ценностей; нарушение правил документооборота и др.;

3) искажение экономических показателей с целью уменьшения размера налогооблагаемой базы: завышение стоимости приобретенного сырья, топлива, услуг, относимых на издержки производства; неотражение или неправильное отражение курсовых единиц по оприходованной валюте; неотражение или неправильное отражение результатов переоценки имущества предприятия; отнесение затрат по ремонту на себестоимость продукции при наличии сформированного ремонтного фонда и др.;
4) искажение объекта налогообложения: занижение объема (стоимости) реализованной продукции, работ, услуг. Это один из самых распространенных в наши дни способов уклонения от уплаты налогов. Обычно в таком случае все записи составлены верно (род и наименование товара, реквизиты покупателя и т.п.), различие имеется лишь в объеме либо стоимости продукции, отраженной в счетах бухгалтерского учета;

5) маскировка объекта налогообложения: фиктивный бартер; лжеэкспорт; фиктивная сдача в аренду основных фондов; притворная сделка;

6) использование необоснованных изъятий и скидок: отнесение на издержки производства затрат, не предусмотренных законодательством; отнесение на издержки производства затрат в размерах, превышающих установленные законодательством; незаконное использование налоговых льгот;

7) использование сложных схем сокрытия доходов путем создания посреднических аффилированных фирм, в т.ч. зарегистрированных в оффшорных зонах ${ }^{10}$.

В то же время, как представляется, способ совершения преступления не должен иметь значение для квалификации содеянного, следовательно, и указание первого в диспозиции ст. 198 УК РФ не представляется целесообразным.

Во всех случаях совершения уклонения в качестве орудия данного преступления выступает налоговая декларация и иные документы, представление которых в соответствии с законодательством Российской Федерации о налогах и сборах является обязательным.

Налоговая декларация - это письменное заявление налогоплательщика о полученных доходах и произведенных расходах, источниках доходов, налоговых льготах и исчисленной

\footnotetext{
${ }^{10}$ См.: Налоговое право России / Под ред. Ю.А. Крохиной. - М., 2007. - С.128.
} 
сумме налога, а также о других данных, связанных с исчислением и уплатой налога.

Налоговая декларация представляется каждым налогоплательщиком по каждому налогу, подлежащему уплате этим налогоплательщиком, если иное не предусмотрено законодательством о налогах и сборах, в установленной форме, в порядке и в сроки, установленные этим законодательством (пункты 2, 6 и 7 статьи 80 НК РФ).

Под иными документами, указанными в статье 198 УК РФ, следует понимать любые предусмотренные Налоговым кодексом Российской Федерации и принятыми в соответствии с ним федеральными законами документы, служащие основанием для исчисления и уплаты налогов и (или) сборов. К таким документам, в частности, относятся: выписки из книги продаж, из книги учета доходов и расходов хозяйственных операций, копия журнала полученных и выставленных счетов-фактур (статья 145 НК РФ), расчеты по авансовым платежам и расчетные ведомости (статьи 243 и 398 НК РФ), справки о суммах уплаченного налога (статья 244 НК РФ), годовые отчеты (статья 307 НК РФ), документы, подтверждающие право на налоговые льготы ${ }^{11}$.

В качестве последствия совершения уклонения от уплаты налогов (сборов) выступает причинённый бюджету ущерб в крупном (особо крупном) размере.

В ныне действующей редакции примечания 1 к ст.198 УК РФ под крупным размером ущерба понимается сумма налогов и (или) сборов, составляющая за период в пределах 3-х финансовых лет подряд более 600000 рублей, при условии, что доля неуплаченных налогов и (или) сборов превышает 10 \% подлежащих уплате сумм налогов и (или) сборов, либо пре-

\footnotetext{
${ }^{11}$ П.4-5 Постановления Пленума Верховного Суда РФ от 28 декабря 2006 г. №64 «О практике применения судами уголовного законодательства об ответственности за налоговые преступления» // СПС «КонсультантПлюс».
}

вышающая 1800000 рублей, а особо крупным размером - сумма, составляющая за период в пределах 3-х финансовых лет подряд более 3000000 рублей, при условии, что доля неуплаченных налогов и (или) сборов превышает $20 \%$ подлежащих уплате сумм налогов и (или) сборов, либо превышающая 9000000 рублей.

Таким образом, состав преступления, предусмотренного ст. 198 УК РФ, являются по конструкции материальными: момент фактической неуплаты налогов (сборов) в срок, установленный налоговым законодательство $P \Phi^{12}$, и момент причинения бюджету ущерба в крупном (особо крупном) размере совпадают.

Заметим, что ряд авторов считают составы данных преступлений формальным ${ }^{13}$. В то же время, если бы это действительно было так, то для наступления уголовной ответственности за уклонение достаточно было бы совершения действий (бездействия), предусмотренных в диспозиции «налоговой» статьи УК РФ. Но в таком случае возник бы вопрос о разграничении уголовно наказуемого деяния и налогового правонарушения, совершение которого также не предполагает наступления ущерба в крупном (особо крупном) размере. Как видим, наступление уголовной ответственности является следствием причинения ущерба в крупном (особо крупном) размере, что с неизбежностью предполагает наличие материальной конструкции рассматриваемых составов преступлений.

\footnotetext{
12 П.3 Постановления Пленума Верховного Суда РФ от 28 декабря 2006 г. №64 «О практике применения судами уголовного законодательства об ответственности за налоговые преступления» // СПС «КонсультантПлюс». ${ }^{13}$ См., например: Сверчков В. Уклонение от уплаты обязательных платежей: конструкция составов преступления / В. Сверчков // Российская юстиция. - 2000. - № 7. C. 49; Иванов Н.Г. Уголовная ответственность за уклонение физического лица от уплаты налога / Н.Г. Иванов // Налоговые и иные экономические преступления. Сб. науч. ст. - Ярославль, 2002. С. 12-13; Сабитов Р.А., Пищулин В.Г. Налоговые преступления: уголовно-правовые и криминологические аспекты / Р.А. Сабитов, В.Г. Пищулин. Челябинск, 2001. - С. 34-35 и др.
} 


\section{Налоги и налогообложение - №1(103) • 2013}

Субъективная сторона рассматриваемых преступлений характеризуется виной в форме прямого умысла: лицо осознаёт фактический характер и общественную опасность совершаемых действий (бездействия), предвидит неизбежность причинения в результате указанных действий (бездействия) ущерба бюджету в крупном (особо крупном) размере и желает наступления данных последствий.

Как показывает анализ судебной практики, в ряде случаев при вынесении приговоров суды игнорируют такое обязательное условие наступления уголовной ответственности за уклонение от уплаты налогов (сборов), как совершение данного деяния с прямым умыслом.

Приведём пример. Жуковским районным судом Калужской области 29.01.2001 г. Закирьянов был признан виновным в уклонении от уплаты налога путем непредставления декларации о доходах, совершенном в особо крупном размере, и осужден по ч. 2 ст. 198 УК РФ.

Закирьянов, проживая в 1999 г. на территории Жуковского района Калужской области, согласно договору купли-продажи от 30.07.1999 г. продал Ухиной принадлежавший ему на праве собственности земельный участок с незавершенным строительством жилого дома за 1047225 руб. Полученный в результате сделки доход, облагаемый налогом, составил 629775 руб. Подлежащий уплате налог с дохода - 197021 руб. В соответствии с п. 1 ст. 18 действовавшего на момент совершения преступления Закона РФ «О подоходном налоге с физических лиц» Закирьянов был обязан в срок не позднее 30.04.2000 г. представить в ИМНС РФ по Жуковскому району декларацию о фактически полученных доходах и произведенных расходах за 1999 г. Однако в нарушение данных требований он, уклоняясь от уплаты подоходного налога, этого не сделал и причитающийся к уплате налог в сумме 197021 руб. в установленные законодательством сроки не уплатил.
Судебная коллегия по уголовным делам Калужского областного суда приговор оставила без изменения.

Заместитель Председателя Верховного Суда РФ в протесте поставил вопрос об отмене судебных решений и направлении дела на новое судебное рассмотрение.

Президиум Калужского областного суда 08.05.2002 г. протест удовлетворил по следующим основаниям.

В соответствии с требованиями ст. ст. 309 и 314 еще действовавшего в тот период УПК РСФСР (п. 4 ст. 302, ст. 307 УПК РФ) обвинительный приговор постановляется лишь при условии, что в ходе судебного разбирательства виновность подсудимого в совершении преступления доказана, а описательная часть приговора должна содержать, в частности, описание преступного деяния, признанного доказанным, с указанием места, времени, способа его совершения, формы вины, мотивов, целей и последствий преступления, а также доказательства, на которых основаны выводы суда.

Указанные требования уголовно-процессуального закона судом по делу Закирьянова выполнены не были.

В подтверждение вины Закирьянова в совершении рассматриваемого преступления суд в приговоре сослался на показания свидетелей Ухиной, Павленковой, Долженкова и Беловой, а также на извещение осужденного о необходимости его явки в налоговую инспекцию и на договор купли-продажи недвижимости.

По смыслу ч. 2 ст. 198 УК РФ уклонение от уплаты налогов совершается исключительно с прямым умыслом. Несвоевременная же подача декларации о доходах, не связанная с намерением уклониться от уплаты налога, а равно искажение данных о фактически полученных доходах или понесенных при этом расходах, происшедшее по ошибке, не влекут уголовной ответственности. 
Без всестороннего выяснения обстоятельств по делу суд сделал вывод о наличии в действиях осужденного прямого умысла на совершение данного преступления.

Согласно показаниям осужденного Закирьянова, на которые суд сослался в приговоре в подтверждение его вины в совершении преступления, при продаже им дома в июне 1999 г. участвовал нотариус, во время совершения сделки объяснивший ему, что документы будут направлены в налоговую инспекцию. 05.04.2000 г. Закирьянов заключил договор консалтинговых услуг с фирмой ООО «МТЦ Альфа» о составлении декларации о доходах и направлении ее в налоговую инспекцию. Он был уверен, что декларация поступила в налоговую инспекцию. В мае 2000 г. он у налогового инспектора интересовался о наличии или отсутствии к нему каких-либо претензий, однако таковых не было. В конце сентября 2000 г., когда он находился в командировке в г. Свердловске, ему стало известно, что им интересуется налоговая полиция, и 02.10.2000 г. сам связался по телефону с работником налоговой полиции и из разговора понял, что его декларация в налоговую инспекцию не поступила. По возвращении из командировки он собрал копии декларации и документов и представил их в налоговую инспекцию, но поскольку они были приняты как поступившие впервые, то за несвоевременное предоставление декларации Закирьянов был привлечен к административной ответственности. Умысла на уклонение от уплаты налогов у него не было.

Показания осужденного надлежало всесторонне проверить и дать им оценку в совокупности с другими имеющимися в материалах дела доказательствами. Однако суд первой инстанции этого не сделал, хотя в материалах дела имеются данные, частично подтверждающие показания Закирьянова в указанной части.

Так, к делу была приобщена копия договора консалтинговых услуг от 05.04.2000 г., согласно которому фирма ООО «МТЦ Альфа» взяла на себя обязательство в срок не позднее 30.04.2000 г. представить в налоговую инспекцию по месту жительства Закирьянова оригинал декларации о его доходах за 1999 г.

Согласно приведенным в приговоре показаниям свидетеля Долженкова - налогового инспектора - Закирьянов действительно обращался к нему в мае 2000 г. по поводу получения справки, однако он (Долженков) не помнит, спрашивал ли Закирьянов о наличии к нему каких-либо претензий.

Эти доказательства надлежащей оценки в приговоре не получили. Более того, из приговора не видно, какие конкретно показания Долженкова опровергают доводы осужденного об отсутствии к нему каких-либо претензий со стороны налоговой инспекции.

Суд первой инстанции обосновывал свой вывод об уклонении Закирьянова от уплаты налогов справкой ИМНС РФ по Жуковскому району от 04.11.2000 г., согласно которой его декларация о доходах в установленные законом сроки по почте в налоговую инспекцию не поступила, а также результатами проверки органами следствия мета нахождения фирмы ООО «МТЦ Альфа», установивших, что такая фирма по указанному в декларации адресу отсутствует. В то же время суд не дал в приговоре оценку показаниям свидетеля Беловой - начальника отдела налогообложения физических лиц налоговой инспекции, пояснившей, что вся поступающая в налоговую инспекцию корреспонденция регистрируется не по наименованию или фамилии отправителя, а лишь по номерам и упомянутая проверка ошибочно проводилась по иному, нежели значится в договоре консалтинговых услуг, адресу.

Суд кассационной инстанции данные обстоятельства также оставил без внимания.

Следовательно, приговор и определение кассационной инстанции обоснованными и законными назвать нельзя, в связи с чем они 


\section{Налоги и налогообложение - №1(103) • 2013}

подлежат отмене. Дело было направлено на новое рассмотрение ${ }^{14}$.

Субъектом преступления, предусмотренного статьей 198 УК РФ, является достигшее шестнадцатилетнего возраста физическое лицо (гражданин Российской Федерации, иностранный гражданин, лицо без гражданства), на которое в соответствии с законодательством о налогах и сборах возложена обязанность по исчислению и уплате в соответствующий бюджет налогов и (или) сборов, а также по представлению в налоговые органы налоговой декларации и иных документов, необходимых для осуществления налогового контроля, представление которых в соответствии с законодательством Российской Федерации о налогах и сборах является обязательным. В частности, в силу статьи 11 НК РФ им может быть индивидуальный предприниматель, зарегистрированный в установленном порядке и осуществляющий предпринимательскую деятельность без образования юридического лица, а также частный нотариус, адвокат, учредивший адвокатский кабинет.

В соответствии с Постановлением Пленума Верховного Суда РФ от 28 декабря 2006 г. № 64 субъектом преступления, ответственность за которое предусмотрена статьей 198 УК РФ, может быть и иное физическое лицо, осуществляющее представительство в совершении действий, регулируемых законодательством о налогах и сборах, поскольку в соответствии со статьями 26, 27 и 29 НК РФ налогоплательщик (плательщик сборов) вправе участвовать в таких отношениях через законного или уполномоченного представителя, если иное не предусмотрено Налоговым кодексом Российской Федерации.

В тех случаях, когда лицо, фактически осуществляющее свою предпринимательскую деятельность через подставное лицо (например, безработного, который формально был зарегистрирован в качестве индивидуального

${ }^{14}$ См.: Бюллетень Верховного Суда РФ. - 2003. - №5. предпринимателя), уклонялось при этом от уплаты налогов (сборов), его действия следует квалифицировать по статье 198 УК РФ как исполнителя данного преступления, а действия иного лица в силу части четвертой статьи 34 УК РФ - как его пособника при условии, если он сознавал, что участвует в уклонении от уплаты налогов (сборов) и его умыслом охватывалось совершение этого преступления.

В то же время применение многих из указанных в Постановлении разъяснений вызывает некоторые сложности на практике.

В частности, вызывает вопросы положение о том, что субъектом преступления, ответственность за которое предусмотрена статьей 198 УК РФ, может быть и иное физическое лицо, являющееся законным или уполномоченным представителем налогоплательщика (плательщика сбора).

В соответствии с абз.1 ч.1 ст.45 НК РФ налогоплательщик обязан самостоятельно исполнить обязанность по уплате налога, если иное не предусмотрено законодательством о налогах и сборах. Из указанной формулировки не ясно, что конкретно подразумевается под самостоятельным исполнением обязанности по уплате налога и какие случаи признаются исключением из этого правила. В результате наличие в налоговом законодательстве РФ подобной неопределенности возникают многочисленные споры между налогоплательщиками и налоговыми органами по поводу возможности уплаты налога представителем налогоплательщика, по результатам которых суды выносили противоположные решения и приговоры. Думается, устранению подобного недостатка налогового законодательства РФ способствовало бы изложение абз.1 ч.1 ст.45 НК РФ в следующей редакции: «1. Налогоплательщик обязан самостоятельно либо через законного или уполномоченного представителя исполнить обязанность по уплате налога, если иное не предусмотрено законодательством о налогах и сборах». 


\section{Библиография:}

1. Александров И.В. Налоговые преступления: криминалистические проблемы расследования. - СПб., 2002.

2. Александров И.В. Основы налоговых расследований/ И.В. Александров. - СПб., 2003.

3. Волженкин Б.В. Преступления в сфере экономической деятельности по уголовному праву. М., 2007.

4. Егоров В.А. Налоговые преступления и их предупреждение: Автореф. дис. ... канд. юрид. наук. - Самара, 1999.

5. Иванов Н.Г. Уголовная ответственность за уклонение физического лица от уплаты налога / Н.Г. Иванов // Налоговые и иные экономические преступления. Сб. науч. ст. - Ярославль, 2002.

6. Кашубин Д.Ю. Налоговые преступления в уголовном праве России: Автореф. дис. ... канд. юрид. наук. - М., 2002.

7. Кучеров И. Налоги и криминал: Историкоправовой анализ / И.И. Кучеров. - М., 2000.

8. Кучеров И.И., Соловьев И. Н. Уголовная ответственность за налоговые преступления / И.И. Кучеров, И.Н. Соловьёв. - М., 2004.

9. Макаров Д. Г. Теневая экономика и уголовный закон / Д.Г. Макаров. М., 2003.

10. Налоговое право России / Под ред. Ю.А. Крохиной. - М., 2007.

11. Ожегов С.И. Словарь русского языка / С.И. Ожегов. - М., 1994.

12. Сабитов Р.А., Пищулин В.Г. Налоговые преступления: уголовно-правовые и криминологические аспекты / Р.А. Сабитов, В.Г. Пищулин. - Челябинск, 2001.

13. Сверчков В. Уклонение от уплаты обязательных платежей: конструкция составов преступления / В. Сверчков // Российская юстиция. -2000 . - № 7.

14. Соловьев И. Н. Уголовная ответственность за уклонение от уплаты налогов и сборов / И.Н. Соловьёв. - М., 2000.

\section{References (transliteration):}

1. Aleksandrov I.V. Nalogovye prestupleniya: kriminalisticheskie problemy rassledovaniya. - SPb., 2002.

2. Aleksandrov I.V. Osnovy nalogovykh rassledovaniy/ I.V. Aleksandrov. - SPb., 2003.

3. Volzhenkin B.V. Prestupleniya v sfere ekonomicheskoy deyatel'nosti po ugolovnomu pravu. M., 2007.

4. Egorov V.A. Nalogovye prestupleniya i ikh preduprezhdenie: Avtoref. dis. ... kand. yurid. nauk. - Samara, 1999.

5. Ivanov N.G. Ugolovnaya otvetstvennost' za uklonenie fizicheskogo litsa ot uplaty naloga / N.G. Ivanov // Nalogovye i inye ekonomicheskie prestupleniya. Sb. nauch. st. - Yaroslavl', 2002.

6. Kashubin D.Yu. Nalogovye prestupleniya v ugolovnom prave Rossii: Avtoref. dis. ... kand. yurid. nauk. - M., 2002.

7. Kucherov I. Nalogi i kriminal: Istorikopravovoy analiz / I.I. Kucherov. - M., 2000.

8. Kucherov I.I., Solov'ev I. N. Ugolovnaya otvetstvennost' za nalogovye prestupleniya / I.I. Kucherov, I.N. Solov'ev. - M., 2004.

9. Makarov D. G. Tenevaya ekonomika i ugolovnyy zakon / D.G. Makarov. M., 2003.

10. Nalogovoe pravo Rossii / Pod red. Yu.A. Krokhinoy. - M., 2007.

11. Ozhegov S.I. Slovar' russkogo yazyka / S.I. Ozhegov. - M., 1994.

12. Sabitov R.A., Pishchulin V.G. Nalogovye prestupleniya: ugolovno-pravovye i kriminologicheskie aspekty / R.A. Sabitov, V.G. Pishchulin. - Chelyabinsk, 2001.

13. Sverchkov V. Uklonenie ot uplaty obyazatel'nykh plat ezhey: konstruktsiya sostavov prestupleniya / V. Sverchkov // Rossiyskaya yustitsiya. - 2000. - № 7.

14. Solov'ev I. N. Ugolovnaya otvetstvennost' za uklonenie ot uplaty nalogov i sborov / I.N. Solov'ev. - M., 2000. 